\title{
Risk Factors for Nosocomial Infections in Neonatal Intensive Care Unit
}

\author{
Ingrid Rita Situmorang, Herry Garna \\ (Department of Child Health, School of Medicine \\ Padjadjaran University - Hasan Sadikin Hospital, Bandung)
}

\begin{abstract}
We report our study to determine factors associated with increased nosocomial infections in neonates hospitalized in NICU, from January until December, 1992. A total number of 116 infants were studied, $68(58.6 \%)$ of them were male, and 101 $(87.1 \%)$ were less than 6 days old. Forty six infants $(39.8 \%)$ had a birth weight of $<1500$ $\mathrm{g}, 27(23.3 \%)$ between $1500-1999 \mathrm{~g}, 14(12.1 \%)$ between $2000-2499 \mathrm{~g}, 27(23.2 \%)$ $>2500 \mathrm{~g}$, and $2(1.7 \%)$ were unknown. A total number of 64 infants $(55.2 \%)$ had more than 1 infections, yielding 103 episodes of infection, giving an incidence of $88.8 \%$ infection rate. The significant risk factor for nosocomial infections was length of hospital stay. Age, birth weight, gestational age, APGAR scores, use of nasogastric tube or intravenous line, were not statistically significant risk factors. Use of nasogastric tube was associated with increased nosocomial gastroenteritis, compared with use of intravenous lines. [Paediat Indones 1994; 34:48-56]
\end{abstract}

\section{Introduction}

Neonates, particularly preterm infants, are highly susceptible to infection due to the limited competence in their immunological system. ${ }^{1-3}$ Neonates appear not only to be at a high risk for infection but also to have more severe disease when

Accepted for publication: December 10, 1993. For correspondence: Ingrid R Situmorang, MD. Department of Child Health, Medical School, Padjadjaran University Hasan Sadikin Hospital, Jalan Pasteur No. 38, Bandung, Indonesia. compared with older babies. ${ }^{4}$ Nosocomial infections are relatively uncommon in normal, fullterm infants; the rate ranges from 0.5 to $1.7 \%$ In contrast, the rates of infection among low birth weight infants in neonatal intensive care units are higher than in any other unit in the hospital. Hemming et al. ${ }^{6}$ studied 904 infants and found nosocomial infection in $153 \%$ of the infants. ${ }^{6}$ The rates of nosocomial infection in such infants vary from $5 \%$ $25 \%{ }^{3}$ and $20 \% 30 \%{ }^{5}$ and increase with the increase of length of hospitalization. 
The development of neonatal intensive care units has reduced the mortality of sick infants; on the other hand, it also introduces devices and techniques for diagnostic and therapeutic purposes with their potential complications. ${ }^{7}$

Infants with birth weight of less than $1500 \mathrm{~g}$ are susceptible to infection. Goldman et al. studied nosocomial infections in the NICU of the Children's Hospital Medical Center, Boston, and found that there was an increased risk of infection associated with low birth weight, patent ductus arteriosus, surgery, and multiple invasive supportive procedures. ${ }^{8}$

The purpose of this study was to determine risk factors for the occurrence of nosocomial infections according to site of infections in the neonatal intensive care unit setting.

\section{Methods}

The study was performed on babies admitted to the NICU at the Department of Child Health, Medical School, Padjadjaran University-Hasan Sadikin Hospital, from January 1 to December 31, 1992, who developed nosocomial intection.

All medical records were studied carefully; information collected included age, sex, birth weight, gestational age, Apgar score at 1 and 5 minutes, feeding pattern (i.e., breast milk, artificial milk, nasogastric tube, intravenous lines), date of admission, date of discharge, diagnosis, and mortality.

Data of nosocomial infections according to site of infections and risk factors which influence the occurrence of nosocomial infections were documented. Risk factors studied were age, birth weight, gestational age, Apgar score at 1 and 5 minutes, length of hospital stay, and feeding pattern (nasogastric tube or intravenous lines).

The definition for nosocomial infection in this study followed those of CDC. ${ }^{9}$ The data was managed using program SPSS$\mathrm{PC}$ version 3.0. Statistical analyses were performed using chi-square, Odds ratio, and multiple logistic regression analysis.

\section{Results}

There were 116 babies admitted to the NICU during the study period. Their characteritics are depicted in Tables 1 and 2 .

\section{Site of Infections}

Blood (bacteremia) was the most frequent site of nosocomial infections, i.e., $33.0 \%$ followed by gastrointestinal tract $(31.1 \%)$, skin $(22.2 \%)$, lower respiratory tract $(4.9 \%)$, postoperative wound $(1 \%)$ and others $7.8 \%$ (stomatitis, omphalitis, and conjunctivitis) Phlebitis was the most frequent type of nosocomial skin infections on the head.

The most frequently isolated microorganism from the blood was Klebsiella species detected in 22 infants $(64.7 \%)$, followed by Pseudomonas species in 7 $(20.6 \%)$, Staphylocoocus albusin $3(8.8 \%)$ and $E$. intermedius in 2 infants $(5.9 \%)$.

\section{Risk Factors}

Of total number of 116 infants hospitalized in the NICU, 64 infants $(55.2 \%)$ acquired nosocomial infections with 103 episodes of infection, giving an incidence of $88.8 \%$ nosocomial infection rate. 
The association between risk factors and nosocomial infections is depicted in Table 3. The influencing risk factors for nosocomial infections in this study was the hospital stay ( $p=0.00001)$. The longer the hospital stay, the higher the number of nosocomial infections. Other risk factors did not give significant association. Nasogastric tube feeding increased the risk of nosocomial gastroenteritis compared to intravenous lines $(p=0.001)$.

Of 64 infants with nosocomial infections, 35 infants $(54.7 \%)$ showed 1 episode, while $21(32.8 \%), 6(9.4 \%)$, and 2 (3.1\%) infants were found to have 2,3 , and 4 episodes of nosocomial infection, respectively. When infants with nosocomial infections were further subdivided into 1 and $>2$ episodes, it became more clear that those risk factors failed to give any statistically significant association (Table 4). Further analysis was done with cross tabulation between infants with and without nosocomial infections among the influencing risk factors with birth weight and gestational age as confounding factors (Table 5 and 6 ).

\section{Mortality}

The mortality of the infants with and without nosocomial infections did not different significantly (Table 7). This may be caused by the severe underlying disease of the infa its.

\section{Discussion}

Nosocomial infections result in considerable morbidity and mortality, prolongation of hospitalization, and increase in indirect and direct patient care expendit-
Table 1. Age and sex distribution of 116 infant studied

\begin{tabular}{|c|c|c|c|c|c|c|}
\hline \multirow[b]{2}{*}{ SEX } & \multicolumn{3}{|c|}{ Age (days) } & \multicolumn{2}{|c|}{ Total } & \\
\hline & & $0-6$ & $>6$ & & & \\
\hline & $n$ & $\%$ & $\mathrm{n}$ & $\%$ & $\mathrm{~N}$ & $\%$ \\
\hline $\begin{array}{l}\text { B oy } \\
\text { Girl }\end{array}$ & $\begin{array}{l}60 \\
41\end{array}$ & $\begin{array}{l}51.7 \\
35.4\end{array}$ & $\begin{array}{l}8 \\
7\end{array}$ & $\begin{array}{l}6.9 \\
6.0\end{array}$ & $\begin{array}{l}68 \\
48\end{array}$ & $\begin{array}{l}58.6 \\
41.4\end{array}$ \\
\hline Total & 101 & 87.1 & 15 & 12.9 & 116 & 100.0 \\
\hline
\end{tabular}

Table 2. Characteristics of 116 infants studied according to age and birth weight

\begin{tabular}{lllllll}
\hline \multirow{2}{*}{ Birth Weight } & \multicolumn{3}{c}{ Age (days) } & \multicolumn{3}{l}{} \\
& & & & & & \multicolumn{2}{l}{ Total } \\
\hline (grams) & $n$ & $\%$ & $n$ & $\%$ & $n$ & $\%$ \\
\hline$<1500$ & 46 & 39.8 & 0 & - & 46 & 39.8 \\
$1500-1999$ & 22 & 18.9 & 5 & 4.3 & 27 & 23.2 \\
$2000-2499$ & 11 & 9.5 & 3 & 2.6 & 14 & 12.1 \\
$\geq 2500$ & 22 & 18.9 & 5 & 4.3 & 27 & 23.2 \\
Unknown & 0 & - & 2 & 1.7 & 2 & 1.7 \\
\hline Total & 101 & 87.1 & 15 & 12.9 & 116 & 100.0 \\
\hline
\end{tabular}

ures. $^{10}$ The high morbidity and mortality rates of nosocomial infection constitute a serious problem, especially in developing cusntries. The highest nosocomial infection rates are reported to occur in neonatal and pediatric intensive care units.

\section{Age}

In general, nosocomial infections are more severe in very young and old patients. Milliken et al. found that patients less than 2 years old, particularly those between 7 and 30 days of age had the highest rate of infection. ${ }^{11}$ In neonates, low gestational age (prematurity) has been shown to predispose to nosocomial
Table3. Association between the influencing risk factors for nosocomial infections

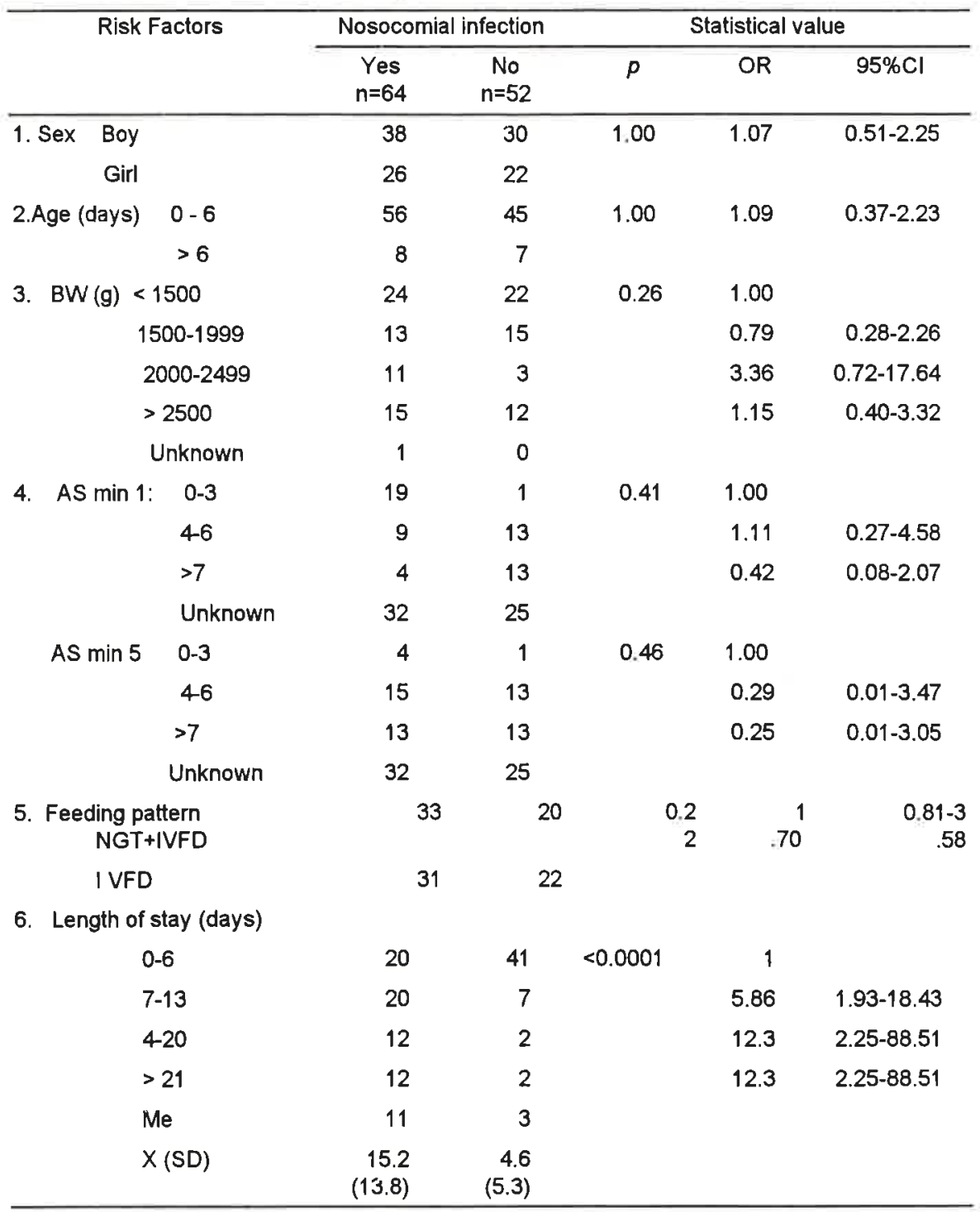

OR=Odds ratio; $\mathrm{Cl}=$ Confidence intervals; $S D=$ standard deviation; Me=Median; $\mathrm{X}=$ Mean 
Table 4. Characteristics of 64 infants with nosocomial infection according to 1 and $\geq 2$ episodes of infection.

\begin{tabular}{|c|c|c|c|c|c|}
\hline \multirow[t]{2}{*}{ Characteristics } & \multicolumn{2}{|c|}{$\begin{array}{l}\text { No of Nosoco- } \\
\text { mial infection } \\
\text { episode }\end{array}$} & \multicolumn{3}{|c|}{ Statistical value } \\
\hline & $\begin{array}{c}1 \\
(n=35)\end{array}$ & $\begin{array}{c}>2 \\
(n=29)\end{array}$ & $p$ & OR & $\mathrm{Cl}$ \\
\hline \multicolumn{6}{|l|}{ 1. Sex } \\
\hline Boy & 21 & 17 & 1 & 1.06 & $0.39-2.88$ \\
\hline Girl & 14 & 12 & & & \\
\hline \multicolumn{6}{|l|}{ 2. Ages (days) } \\
\hline $0-6$ & 32 & 24 & 0.5 & 2.22 & $0.48-10.22$ \\
\hline$>6$ & 3 & 5 & & & \\
\hline \multicolumn{6}{|l|}{ 3. Birth Weight (g) } \\
\hline$<1500$ & 16 & 8 & 0.25 & 1 & \\
\hline $1500-1999$ & 6 & 7 & & 0.43 & $0.88-2.09$ \\
\hline 2000-2499 & 6 & 5 & & 0.6 & $0.11-3.24$ \\
\hline$>2500$ & 7 & 8 & & 0.44 & $0.09-1.98$ \\
\hline Unknown & 0 & 1 & & & \\
\hline \multicolumn{6}{|l|}{ 4. AS $1 \mathrm{~min}$} \\
\hline $0-3$ & 10 & 9 & 0.08 & 1 & \\
\hline $4-6$ & 6 & 3 & & 1.8 & $0.27-12.94$ \\
\hline$>6$ & & 4 & & 0 & $0.00-1.90$ \\
\hline \multicolumn{6}{|l|}{ AS $5 \mathrm{~min}$} \\
\hline $0-3$ & 2 & 2 & 0.93 & 1 & \\
\hline 46 & 8 & 7 & & 1.14 & $0.08-16.44$ \\
\hline$>6$ & 6 & 7 & & 0.86 & $0.06-12.93$ \\
\hline \multicolumn{6}{|l|}{ 5. Feeding pattern } \\
\hline NGT (+IVFD) & 14 & 19 & 0.74 & 0.35 & $0.12-0.97$ \\
\hline IVFD & 21 & 10 & & & \\
\hline \multicolumn{6}{|c|}{ 6. Length of stay (d) } \\
\hline $0-6$ & 14 & 6 & 0.39 & 1 & \\
\hline $7-13$ & 10 & 10 & & 0.43 & $0.09-1.87$ \\
\hline 1420 & 5 & 7 & & 0.31 & $0.05-1.71$ \\
\hline$>21$ & 6 & 6 & & 0.43 & $0.07-2.37$ \\
\hline
\end{tabular}

Table 5. Cross tabulation between infants with and without nosocomial infection among the risk factors with birth weight as a confounding factor

\begin{tabular}{|c|c|c|c|c|}
\hline \multirow[t]{2}{*}{$\begin{array}{l}\text { Risk } \\
\text { Factors }\end{array}$} & \multirow{2}{*}{$\begin{array}{l}\text { Bith } \\
\text { Weight } \\
\text { (gram) }\end{array}$} & \multicolumn{2}{|c|}{$\begin{array}{l}\text { Nosocomial } \\
\text { infection }\end{array}$} & \multirow[t]{2}{*}{$\begin{array}{c}\text { Statistical } \\
\text { Value }\end{array}$} \\
\hline & & $\begin{array}{l}\text { Yes } \\
n=64\end{array}$ & $\begin{array}{c}\text { No } \\
n=52\end{array}$ & \\
\hline \multicolumn{5}{|l|}{ Age (days) } \\
\hline \multirow[t]{2}{*}{$0-6$} & $<2000$ & 33 & 35 & $x^{2}=4.86$ \\
\hline & $2000+$ & 23 & 10 & \\
\hline \multirow[t]{2}{*}{$>6$} & $<2000$ & 4 & 1 & $x^{2}=9.78$ \\
\hline & $2000+$ & 7 & 6 & $p=0.02$ \\
\hline \multicolumn{5}{|l|}{$\begin{array}{l}\text { Feeding } \\
\text { pattern }\end{array}$} \\
\hline \multirow[t]{2}{*}{$N G T+I V F D$} & $<2000$ & 7 & 2 & $x^{2}=2.23$ \\
\hline & $2000+$ & 8 & 6 & $p=0.26$ \\
\hline \multirow[t]{2}{*}{ IVFD } & $<2000$ & 22 & 28 & $x^{2}=4.32$ \\
\hline & $2000+$ & 14 & 12 & $\rho=0.23$ \\
\hline \multicolumn{5}{|l|}{ AS $1 \mathrm{~min}$} \\
\hline \multirow[t]{2}{*}{$0-3$} & $<2000$ & 12 & 13 & $x^{2}=6.05$ \\
\hline & $2000+$ & & & \\
\hline \multirow[t]{2}{*}{$4-6$} & $<2000$ & 7 & 3 & $x^{2}=2.86$ \\
\hline & $2000+$ & 2 & 3 & \\
\hline \multirow[t]{2}{*}{$>7$} & $<2000$ & 2 & 6 & $x^{2}=3.89$ \\
\hline & $2000+$ & 2 & 4 & \\
\hline \multicolumn{5}{|l|}{ AS 5 min } \\
\hline \multirow[t]{2}{*}{$0-3$} & $<2000$ & 2 & 0 & $x^{2}=1.87$ \\
\hline & $2000+$ & 2 & 1 & \\
\hline \multirow[t]{2}{*}{46} & $<2000$ & 10 & 13 & $x^{2}=6.69$ \\
\hline & $2000+$ & 5 & 0 & \\
\hline \multirow[t]{2}{*}{$>7$} & $<2000$ & 9 & 9 & $x^{2}=2.67$ \\
\hline & $2000+$ & 2 & 4 & \\
\hline
\end{tabular}

Table 6. Cross tabulation between infants with and without nosocomial infection among the risk factors with gestational age as a confounding tactor.

\begin{tabular}{|c|c|c|c|c|}
\hline \multirow[t]{2}{*}{$\begin{array}{l}\text { Risk } \\
\text { Factors }\end{array}$} & \multirow{2}{*}{$\begin{array}{l}\text { Gestation- } \\
\text { al age } \\
\text { (Weeks) }\end{array}$} & \multicolumn{2}{|c|}{$\begin{array}{c}\text { Nosocomial } \\
\text { Infection }\end{array}$} & \multirow[t]{2}{*}{$\begin{array}{l}\text { Statistical } \\
\text { Value }\end{array}$} \\
\hline & & $\begin{array}{l}\text { Yes } \\
n=55\end{array}$ & $\begin{array}{l}\text { No } \\
n=43\end{array}$ & \\
\hline \multicolumn{5}{|l|}{ Age (days) } \\
\hline \multirow[t]{2}{*}{$0-6$} & $28-32$ & 23 & 14 & $x^{2}=1.09$ \\
\hline & $33+$ & 26 & 23 & \\
\hline \multirow[t]{2}{*}{$>6$} & $28-32$ & 4 & 0 & $x^{2}=12.00$ \\
\hline & $33+$ & 2 & 6 & \\
\hline \multicolumn{5}{|l|}{$\begin{array}{l}\text { Feeding } \\
\text { pattern }\end{array}$} \\
\hline \multirow[t]{2}{*}{ NGT +IVFD } & $28-32$ & 16 & 3 & $x^{2}=8.53$ \\
\hline & $33+$ & 13 & 14 & $p=0.07$ \\
\hline \multirow[t]{2}{*}{ IVFD } & $28-32$ & 11 & 11 & $x^{2}=0.22$ \\
\hline & $33+$ & 15 & 15 & \\
\hline \multicolumn{5}{|l|}{ AS $1 \mathrm{~min}$} \\
\hline \multirow[t]{2}{*}{$0-3$} & $28-32$ & 6 & 3 & $x^{2}=1.66$ \\
\hline & $33+$ & 8 & 6 & \\
\hline \multirow[t]{2}{*}{46} & $28-32$ & 4 & 2 & $x^{2}=6.37$ \\
\hline & $33+$ & 4 & 4 & \\
\hline \multirow[t]{2}{*}{$>7$} & 38-32 & 3 & 3 & $x^{2}=4.51$ \\
\hline & $33-34$ & 1 & 5 & \\
\hline \multicolumn{5}{|l|}{ AS $5 \mathrm{~min}$} \\
\hline \multirow[t]{2}{*}{$0-3$} & $28-32$ & 2 & 0 & $\times 2=5.00$ \\
\hline & $33+$ & 2 & 1 & \\
\hline \multirow[t]{2}{*}{$4-6$} & $28-32$ & 4 & 3 & $x 2=3.95$ \\
\hline & $33+$ & 4 & 5 & \\
\hline \multirow[t]{2}{*}{$>7$} & $28-32$ & 7 & 3 & $\times 2=6.34$ \\
\hline & $33+$ & 6 & 7 & \\
\hline
\end{tabular}


Table 7. Distribution of mortality of the infants with and without nosocomial infection

\begin{tabular}{cccc}
\hline $\begin{array}{c}\text { Nosocomial } \\
\text { infection }\end{array}$ & $n$ & $\begin{array}{c}\text { Died } \\
(\%)\end{array}$ & $\begin{array}{c}\text { Survived } \\
(\%)\end{array}$ \\
\hline Yes & 64 & $\begin{array}{c}45 \\
(70.3)\end{array}$ & $\begin{array}{c}19 \\
(19.7)\end{array}$ \\
No & 52 & $\begin{array}{c}36 \\
(69.2)\end{array}$ & $\begin{array}{c}16 \\
(20.8)\end{array}$ \\
\hline
\end{tabular}

$X^{2}=0.00 ; \mathrm{df}=1 ; p=1.00$

infections, where as those infants with risk factors need an intensive care and monitoring. ${ }^{15,12}$ In this study, infant's age and gestational age failed to show significant influence on nosocomial infection.

\section{Birth weight}

Birth weight is an important determinant of infection risk. An inverse relationship between birth weight and risk of nosocomial infection has been proposed; $9 \%$ of infants weighing $2500 \mathrm{~g}$ or more developed infection compared with $46 \%$ of infants weighing less than 1000 g. ${ }^{6}$ Goldmann estimates that the risk of acquiring nosocomial infection increases 3\% for every $500 \mathrm{~g}$ decrement of birth weight. ${ }^{8}$ Baley pointed the improved survival of very low birth-weight infants who required prolonged hospitalization and many invasive procedures, but increases the risk for nosocomial illnesses. ${ }^{13}$ Boedjang $^{14}$ found nosocomial infection rates in infants weighing $<2500 \mathrm{~g}$ and $>2500$ $\mathrm{g}$ of $7.5 \%$ and $6.5 \%$ respectively and Garna $^{15}$ found that nosocomial infection rates in infants weighing $<1500 \mathrm{~g}$ and $>2500 \mathrm{~g}$ were $29.9 \%$ and $7 \%$, respectively. ${ }^{15}$
Our data showed that there was no significant difference of nosocomial infection rate between infants less than 1500 $\mathrm{g}$ and those of $1500 \mathrm{~g}$ or more. The same was true for infants of less than $2500 \mathrm{~g}$ compared to those of $2500 \mathrm{~g}$ or more.

\section{Hospital stay}

The infection rates also correlate with the length of hospitalization, ${ }^{10}$ since patients who are hospitalized longer would have more chances to expose with the offending microorganisms. Nosocomial infection usually occur after 1-2 weeks of hospitalization, ${ }^{11,16}$ Garna found the incidence of nosocomial infections rose with the increase of length of hospitalization, from $3.2 \%$ in patients hospitalized for up to 6 days, to $48.4 \%$ in patients hospitalized for 35 days or longer. ${ }^{15}$ Our data reconfirmed those previous findings.

\section{Apgar score at 1 minute and 5 minutes}

When infants with Apgar score of 0-3 (severe asphyxia), and 4-6 (mild-moderate asphyxia) were grouped together and compared to those with Apgar score of nore than 7 , there was no statistically different in the rate of nosocomial infection. Similarly, there was no significant difference on the occurrence of nosocomial infection in infants with asphyxia and in those without asphyxia.

\section{Feeding pattern}

There is evidence to believe that use of artificial milk increases the risk of nosocomial gastroenteritis. Epidemiological studies have found that breastfed babies have lower incidence of both morbidity and mortality from infectious illness than do bottle-fed infants. ${ }^{17}$ This reconfirms previous statements that human milk protects the infants against bacterial, viral, and mycoplasma infections. This protection continues throughout the lactation period. It has been established that secretory IgA is found in human milk especially in colostrum; both $T$ and B lymphocytes have also been demonstrated to present in breast mik. ${ }^{18}$ The risk for nosocomial gastroenteritis in infants with artificial milk is 210 greater than in infants with breast milk. ${ }^{15}$

We were unable to determine the role of breast milk in protecting nosocomial infection since no such data are found in the medical record. However we found a significantly higher percentage of nosocomial gastroenteritis in patients using nasogastric tube compared with those receiving intravenous line.

\section{Mortality}

The mortality of the infants with and without nosocomial infections in this study was not statistically significant different. This is may be caused by the severe underlying disease of the infants.

\section{Conclusions}

We found a high incidence of nosocomial infection in neonates hospitalized in the NICU. The most important risk factor for nosocomial infection was tlength of hospital stay; the longer the hospital stay, the higher the number of nosocomial infection. Other factors studied, i.e., age, gestational age, birth weight, and Apgar score showed no significant association with nosocomial infection. Nasogastric tube was associated with the increase incidence of nosocomial gastroenteritis compared with use of intravenous fluid.

\section{References}

1. Causey WA, Gardner P. Hospital control of infections. Nosocomial infections. Textbook of Pediatric Infectious Diseases, vol.II WB Saunders Co, 1981: 1655-93.

2. Wasserman RL. Intravenous gamma globulin prophylaxis for newborn infants. Pediatr Infect Dis 1986; 5: 620-1.

3. Donowitz LG. Nosocomial Infection in neonatal intensive care units. Am J Infect Contr 1989; 17:250-7.

4. Hughes JM, Jarvis WR. Nosocomial gastrointestinal infections. Prevention and Control of Nosocomial Infections. Williams and Wilkins, 1987: 405-39.

5. Gotoff SP. Nosocomial nursery infection. Nelson Textbook of Pediatrics, tion. Nelson Textbook

6. Hemming VG, Overall JC, Britt MR. Nosocomial infections in a newborn intensive care unit: results of fortyone months of surveillance. $\mathrm{N}$ Engl J Med 1976; 294: 1310-6.

7. Myers MG. Longitudinal evaluation of neonatal nosocomial infections: Association of infection with blood pres sure cuff. Pediatrics 1978; 61:42-5.

8. Goldmann DA, Durbin WA Jr, Freeman J. Nosocomial infections in a neonatal intensive car

9. Garner JS, Jarvis WR, Emori TG, Horan TC, Hughes JM. CDC definition for nosocomial infections. Am J Infect Contr 1988; 16:128-40. 
10.Jarvis WR. Epidemiology of nosocomial infections in pediatric patients. Pediat Infect Dis J 1987; 6: 344-51.

11. Milliken J, Tait GA, Ford-Jones EL, Mindorff CM, Gold R, Mullins G. Nosocomial infections in a pediatric intensive care unit. Crit Care Med 1988 ; 16:233-7.

12. Chandrasekar PH, Kruse JA Mathews MF. Nosocomial infection among patients in different types of intensive care units at a city hospital. Crit Care Med 1986; 14:508-10.

13. Baley JE, Kliegman RM, Fanaroff AA. Disseminated fungal infections in very low-birth weight infants: therapeutic tocicity. Pediatrics 1984; 73:153-7.

14.Boedjang RF. Infeksi nosokomial pada neonatus dan bayi. Diajukan pada Penataran dan Latihan Ketrampilan Pengendalian Infeksi Nosokomi- al di RSCM/FKUI, Jakarta, September 1989 .

15. Garna H. Study on nosocomial infections in the Department of Child Health in Hasan Sadikin General Hospital, Padjadjaran University, Bandung, Indonesia. Thesis, 1991.

16. Ford-Jones EL. Epidemiologic study of 1684 hospital-acquired infections in pediatric patients. Paediatr Infect Dis J 1989; 8: 668-75.

17. Dolan SA, Boesman-Finkelstein M, Finkelstein RA. Antimicrobial activity of human milk against pediatric pathogens. J Infect Dis 1986; 154:722-5.

18. Lawrence RA. Host-resistance factors and immunological significance of human milk. In Breast-feeding a guide for the medical profession. St Louis: Mosby Co, 1980;73-91. 